DOI: 10.22620 /agrisci.2021.31.009

\title{
THE EFFECT OF THE SUBSTITUTION OF GRAIN COMPONENTS WITH A HIGH PROPORTION OF BAKERY WASTES ON THE CLARC OF ENERGY DISTRIBUTION AND THE CLARC OF PROTEIN TRANSFORMATION IN THE ECO-TECHNICAL CHAIN 'FODDER - LAYER'S EGGS'
}

\author{
Dimo Penkov $^{1 *}$, Svetlana Grigorova ${ }^{2}$, Alexandar Peltekov ${ }^{1}$ \\ ${ }^{1}$ Agricultural University - Plovdiv, Bulgaria \\ ${ }^{2}$ Institute of Animal Sciences - Kostinbrod, Bulgaria \\ *E-mail: dimopenkov@gmail.com
}

\begin{abstract}
The including of 15 and $20 \%$ bread wastes in the combined fodders for layers of net utilization of energy and protein has been studied. Two new indexes of net utilization have been introduced: Clarc of energy distribution (CED) - the relation between consumed metabolizable energy and accumulated gross energy in the egg mélange and Clarc of protein transformation - the relation between consumed crude protein and accumulated crude protein in the egg mélange. The following results have been established: CED (fodder - egg mélange): Control group $-0.1820 ; 15 \%$ bread wastes $-0.1851 ; 20 \%$ bread wastes -0.1887 ; CPT(fodder - egg mélange) - $0.2358 ; 0.2405$ and 0.2460 respectively. The authors establish a tendency for hens that have consumed more bread wastes to show a higher effectiveness for the net protein transformation.
\end{abstract}

Key words: Clarc of energy distribution, Clarc of protein transformation, fodder, layer's eggs

\section{INTRODUCTION}

The food waste is of great interest both from an environmental point of view (FAO, 2012) and as a substitute for expensive feed components, mainly for domestic pigs and poultry (Paritosh et al., 2017; Yadav et al., 2014). It is essential to establish their nutritional value and the amounts that can be included in the diet of modern breeds and hybrids of animals, without affecting the productivity and efficiency of their economic use (Todorov et al., 1995; Kabakchiev et al., 2014 ; Stoykov \& Katsarov 2010).

In recent years, there has been an increased interest in bakery wastes mainly for two reasons - a significant price increase of grain forages, which are key components in feeding of non-ruminants, and, the relatively short shelf life of bakery products, generating significant amounts of waste after the expiry date, when they are unfit for human consumption (Chung, 2001).

There are data in the world literature for up to $50 \%$ substitution of grain components in compound poultry feed (Al. Tulaihan et al., 2004), but in recent years the effect of supplementing 5 to $10 \%$ extruded bakery waste has been studied (Kricka et al., 2019; Crubor, 2019). Separately, Penkov \& Chobanova (2020) established the metabolizable energy content and the nitrogen digestibility of the product.

The net utilization of energy and nutrients in feed is a major objective criterion for increasing the efficiency of animal feeding (Pirgozliev \& Rose, 1999). In 2018 Penkov \& Genchev (2018) introduced objective criteria (Clarc of energy distribution and Clarc of protein/amino acids transformation) for net utilization of energy and protein and in 2020 Penkov \& Grigorova (2020) adapted the methodology for calculating them in laying hens.

The aim of the present study was to 
establish the effect of higher levels (15 and $20 \%$ ) of substitution of grain components in compound feed for laying hens on the net utilization of energy and protein.

\section{MATERIALS AND METHODS}

An experiment was conducted in the period March-May 2021 at the Poultry Experimental Center of Institute of Animal Science-Kostinbrod with a total of 150 laying hens (35 weeks old) from Lohman Klassik Brown breed. At the beginning of the experiment the poultry were randomly distributed into three groups (control and two experimental groups) in separate boxes, 50 layers each. The hens were housed on a deep litter pen on a $16 \mathrm{~h}$ lighting schedule. The compound feed of the control group had the following composition: maize; soybean meal; sunflower meal; sunflower oil; limestone; monocalcium phosphate; salt; L lysine; mineral premix and vitamin premix. A part of the grain component in the feed of the experimental groups was replaced with $10 \%$ (I experimental group) and $20 \%$ (II experimental group) extruded bread waste. The diets of all groups had the same nutritional value: $11.05 \mathrm{MJ}$ metabolizable energy; $16.7 \%$ crude protein; $0.67 \%$ lysine; $0.65 \%$ methionine+cystine; $4.3 \%$ crude fats; $3.5 \%$ crude fiber; $3.70 \%$ Ca; $0.47 \%$ available P. All the groups received $115 \mathrm{~g}$ feed/day/hen. The duration of the experiment was 68 days.

The laying capacity (in \%), the health status of the birds, the feed provided and the fodder rests were monitored daily. At the beginning and at the end of the experimental period, the following measurements were made on 30 eggs per group: masses of egg, egg yolk, egg white and shell with the sub-shell (with an electronic scale with an accuracy of $\pm 0.01 \mathrm{~g}$ ). The chemical analysis of egg white and yolk was made on 6 eggs per group, with a mass close to the average.

The chemical composition of the feed and the eggs was determined by the Weende method (AOAC, 2007). The metabolic energy of the feed was calculated according to Todorov et al, (2016). The gross energy in the egg melange was calculated according to the formula of Schiemann et al. (1971). The Clarcs of energy distribution (CED) / protein transformation (CPT) were calculated by the original formula (Penkov \& Genchev, 2018):

$\mathrm{CED}=$ Consumed $\mathrm{ME}$ from 1 layer/produced GE through the egg white/yolk/mélange

$\mathrm{CPT}=$ Consumed $\mathrm{CP}$ from 1 layer/produced CP through the egg white/yolk/mélange

\section{RESULTS AND DISCUSSION}

Table 1 shows the amounts of feed, metabolizable energy and crude protein consumed by a laying hen on average throughout the experimental period (entrance of the eco-technical system).

Table 1. Consumed fodder, metabolizable energy (ME) and crude protein (CP) from 1 layer for the whole experimental period (entrance of the system):

\begin{tabular}{|l|l|l|l|}
\hline Indexes & $\begin{array}{l}\text { Control group } \\
\mathrm{x} \pm \mathrm{Sx}\end{array}$ & $\begin{array}{l}\text { First experim. group } \\
(15 \% \text { bread wastes }) \\
\mathrm{x} \pm \mathrm{Sx}\end{array}$ & $\begin{array}{l}\text { Second experim. group } \\
(20 \% \text { bread wastes }) \\
\mathrm{x} \pm \mathrm{Sx}\end{array}$ \\
\hline Consumed fodder $-\mathrm{kg}$ & $7.82 \pm 0.22$ & $7.78 \pm 0.24$ & $7.81 \pm 0.21$ \\
\hline Consumed $\mathrm{ME}-\mathrm{MJ}$ & $86.25 \pm 2.46$ & $85.98 \pm 2.38$ & $86.17 \pm 2.84$ \\
\hline Consumed $\mathrm{CP}-\mathrm{kg}$ & $1.3063 \pm 0.11$ & $1.3017 \pm 0.13$ & $1.2966 \pm 0.009$ \\
\hline
\end{tabular}


When $115 \mathrm{~g}$ compound feed was offered on average, no significant differences were observed in both the total amounts of feed and the metabolizable energy and the crude protein consumed by the birds $(\mathrm{P}>0.05)$.

Total amounts ingested were insignificantly lower than those established in previous studies of the authors (Penkov \&
Grigorova, 2020), due to the smaller amount of the daily offered feed -120 vs. $115 \mathrm{~g}$.

Table 2 presents the chemical composition and the gross energy content in albumen and yolk in the control and in both experimental groups. Although the differences by groups were statistically insignificant $(\mathrm{P}>$ 0.05 ), some tendencies were found.

Table 2. Chemical composition and gross energy (GE) content in the eggs:

\begin{tabular}{|l|l|l|l|}
\hline Indexes & $\begin{array}{l}\text { Control group } \\
\mathrm{x} \pm \mathrm{Sx}\end{array}$ & $\begin{array}{l}\text { First experim. group } \\
(15 \% \text { bread wastes }) \\
\mathrm{x} \pm \mathrm{Sx}\end{array}$ & $\begin{array}{l}\text { Second experim. group } \\
(2 \% \text { bread wastes }) \\
\mathrm{x} \pm \mathrm{Sx}\end{array}$ \\
\hline $\begin{array}{l}\text { Crude protein in egg } \\
\text { white - \% in native }\end{array}$ & $11.21 \pm 0.07$ & $11.05 \pm 0.04$ & $10.91 \pm 0.08$ \\
\hline $\begin{array}{l}\text { Crude protein in egg yolk } \\
-\% \text { in native }\end{array}$ & $16.06 \pm 0.06$ & $16.15 \pm 0.09$ & $16.22 \pm 0.20$ \\
\hline $\begin{array}{l}\text { Crude fats in egg white - } \\
\% \text { in native }\end{array}$ & $0.54 \pm 0.04$ & $0.51 \pm 0.03$ & $0.49 \pm 0.02$ \\
\hline $\begin{array}{l}\text { Crude fats in egg yolk - \% } \\
\text { in native }\end{array}$ & $29.89 \pm 0.23$ & $29.38 \pm 0.22$ & $29.68 \pm 0.17$ \\
\hline $\begin{array}{l}\text { NPE in egg white - \% in } \\
\text { native }\end{array}$ & $0.48 \pm 0.01$ & $0.42 \pm 0.03$ & $0.49 \pm 0.01$ \\
\hline $\begin{array}{l}\text { NPE in egg yolk - \% in } \\
\text { native }\end{array}$ & $0.01 \pm 0.0001$ & $0.02 \pm 0.0001$ & $0.01 \pm 0.0001$ \\
\hline $\begin{array}{l}\text { GE in 1 kg egg white - } \\
\text { MJ in native }\end{array}$ & $2.99 \pm 0.01$ & $2.93 \pm 0.01$ & $14.79 \pm 0.05$ \\
\hline $\begin{array}{l}\text { GE in 1 kg egg yolk - MJ } \\
\text { in native }\end{array}$ & $14.83 \pm 0.03$ & $14.66 \pm 0.04$ & \\
\hline
\end{tabular}

The crude protein content in the egg albumen in the group receiving $20 \%$ of the bakery waste was higher compared to the other two groups, while the protein content in the yolk did not show such a tendency. The content of crude fats in the yolk was also relatively constant.

The slightly higher protein content in the albumen of the third group did not affect its gross energy value, which was comparable with that of the other two groups. The same tendency was observed when comparing the gross energy in the yolk.
The chemical composition and the energy nutrition of the albumen and the yolk in all the three groups did not differ significantly from the official data for the hybrid used (Lohmann Tierzucht, 2019).

The gross energy and the crude protein content in the egg albumen/yolk/melange produced by a laying hen for the whole experimental period are presented in Table 3. In terms of gross energy for both albumen and yolk, there was a statistically insignificant tendency for more energy concentration in the third group $(\mathrm{P}>0.05)$. 
Table 3. Produced gross energy (GE) and crude protein through the egg mélange from 1 layer for the whole experimental period (68 days) and Clarcs of energy distribution (CED) and protein transformation (CPT):

\begin{tabular}{|c|c|c|c|}
\hline Indexes & $\mathrm{x} \pm \mathrm{Sx}$ & $\mathrm{x} \pm \mathrm{Sx}$ & $\mathrm{x} \pm \mathrm{Sx}$ \\
\hline $\begin{array}{l}\text { Produced GE with the egg white from } \\
1 \text { layer for the whole period - MJ }\end{array}$ & $5.19 \pm 0.23$ & $5.23 \pm 0.28$ & $5.37 \pm 0.42$ \\
\hline $\begin{array}{l}\text { Produced GE with the egg white yolk } \\
1 \text { layer for the whole period - MJ }\end{array}$ & $10.52 \pm 0.38$ & $10.67 \pm 0.29$ & $10.92 \pm 0.38$ \\
\hline $\begin{array}{l}\text { Produced CP with the egg white from } \\
1 \text { layer for the whole period }-\mathrm{kg}\end{array}$ & $0.194 \pm 0.006$ & $0.196 \pm 0.008$ & $0.200 \pm 0.007$ \\
\hline $\begin{array}{l}\text { Produced } \mathrm{CP} \text { with the egg white yolk } 1 \\
\text { layer for the whole period }-\mathrm{kg}\end{array}$ & $0.114 \pm 0.003$ & $0.117 \pm 0.002$ & $0.119 \pm 0.004$ \\
\hline $\begin{array}{l}\text { Clarc of energy distribution } \\
\text { (MEfodder-GEegg white) }\end{array}$ & $0.060(6.60 \%)$ & $0.061(6.61 \%)$ & $0.062(6.62 \%)$ \\
\hline $\begin{array}{lll}\text { Clarc of energy } & \text { distribution } \\
\text { (MEfodder-GEegg yolk) } & \end{array}$ & $\begin{array}{l}0.1220 \\
(12.20 \%)\end{array}$ & $\begin{array}{l}0.1241 \\
(12.41 \%)\end{array}$ & $\begin{array}{l}0.1267 \\
(12.67 \%)\end{array}$ \\
\hline $\begin{array}{l}\text { Clarc of energy distribution } \\
\text { (MEfodder-GEegg mélange) }\end{array}$ & $\begin{array}{l}\mathbf{0 . 1 8 2 0} \\
(18.00 \%)\end{array}$ & $\begin{array}{l}\mathbf{0 . 1 8 5 1} \\
(18.51 \%)\end{array}$ & $\begin{array}{l}\mathbf{0 1 8 8 7} \\
(18.87 \%)\end{array}$ \\
\hline $\begin{array}{l}\text { Clarc of protein transformaion } \\
\text { (CPfodder-CPegg white) }\end{array}$ & $\begin{array}{l}0.1485 \\
(14.85 \%)\end{array}$ & $\begin{array}{l}0.1506 \\
(15.06 \%)\end{array}$ & $\begin{array}{l}0.1542 \\
(15.42 \%)\end{array}$ \\
\hline $\begin{array}{l}\text { Clarc of protein transformaion } \\
\text { (CPfodder-CPegg yolk) }\end{array}$ & $0.0873(8.73 \%)$ & $0.0899(8.99 \%)$ & $0.0918 \quad(9.18 \%)$ \\
\hline $\begin{array}{l}\text { Clarc of protein transformaion } \\
\text { (CPfodder-CPegg mélange) }\end{array}$ & $\begin{array}{l}\mathbf{0 . 2 3 5 8} \\
(23.58 \%)\end{array}$ & $\begin{array}{l}\mathbf{0 . 2 4 0 5} \\
(24.05 \%)\end{array}$ & $0.2460(24.60 \%)$ \\
\hline
\end{tabular}

The total crude protein accumulated in the melange of the third group (with $20 \%$ substitution with bakery waste) was significantly higher than in the control $(\mathrm{P} \leq$ 0.05), while the differences between the amounts in the yolk and in the albumen, taken separately, were insignificant.

The energy and the protein utilization from the feed in the experimental laying hens was close to the values obtained by us for the same hybrid (Penkov \& Grigorova, 2020a), but higher for the breeds and hybrids with combined productivity (Lukanov et al., 2016).

In the calculation of Clarcs of energy distribution/protein transformation there was a pronounced tendency to higher net utilization of energy and especially of protein in the group receiving $20 \%$ of the bakery waste compared to the control group. The difference of over $1 \%$ in the protein is of both scientific and purely practical interest, substantiating the reason to continue the research studies in that direction.

\section{CONCLUSION}

In the conditions of the conducted experiment, the following net utilizations of energy and protein have been established:

-Clarc of energy distribution:

- Control group: 0.060 (fodder - egg white); 0.1220 (fodder - egg yolk; 0.1820 (fodder - egg mélange)

- First experimental (with $15 \%$ bread wastes) - respectively $0.061 ; 0.1241$ and 0.1851 .

-Second experimental $(20 \%$ bread wastes) - respectively $0.062 ; 0.1267$ and 0.1887 .

-Clarc of protein transformation:

- Control group: 0.1485 (fodder - egg white); 0.0873 (fodder - egg yolk; 0.2358 (fodder - egg mélange)

- First experimental (with $15 \%$ bread 
wastes) - respectively $0.1506 ; 0.0899$ and 0.2405 .

-Second experimental $(20 \%$ bread wastes) - respectively $0.1542 ; 0.0918$ and 0.2460 .

There is a tendency for the hens that have consumed more bread wastes to show a higher effectiveness for the net protein transformation.

\section{REFERENCES}

Al.Tulaihan, A.A., Najib, H.\& Al-Eid, S.M. (2004). The nutritional evaluation of locally produced dried bakery waste (DBW) in the broiler diets. Pakistan Journal of Nutrition, 3(5), 294-299.

AOAC international (2007). Official methods of analysis of AOAC (18 edition, rev. 2), Association of Official Analytical Chemists Intern., Gaithersburg, MD, USA.

Chung, JC., 2001, Strategy for active recycling of food waste. Journal of Korea Solid Wastes, Engineering Society, 18(8), 2229.

Food and Agriculture Organization of the United Nations - FAO (2011). Global Food Losses and Food Waste - Extent, Causes and Prevention; Food and Agriculture Organization of the United Nations: Rome, Italy.

Kabakchiev, M., Alexieva, D., Genchev, A., Nikolova M. \& Gerzilov, V. (2014). Poultry Breeding. ISBN 9789545172076, 488 (in Bulgarian).

Krička, T., Janječi, Z., Bilandzija, N., Bedekovic, D., Voca, N.,Matin, A., Jurisic, V.\& Crubor, M. (2019). Nutritional usability of thermal treated white and brown bread in broiler feed. Journal of Central European Agriculture, 20(3), 788-795.

Lohmann Tierzucht (2019). Retrieved from: http://www.ltz.de/en/layers/alternativeh ousing/lohmann-brown-classic.php (last accessed).

Lukanov H, Petrov,P, Genchev A, Halil E \& Ismail N. (2016). Productive performance of Easter egger crosses of Araucana and Schijndelaar roosters with white Leghorn hens. Trakia Journal of Sciences, 1: 72 - 79, ISSN 1312-1723.

Paritosh, K., Kyshwaha, S.K.,Yadav, M., Pareek, N., Chawade, A., Vivekanand \& V. (2017). Food waste to energy: An overview of sustainable approaches for food waste management and nutrient recycling. BioMed Research International, 2017(2):1-19.

Penkov, D.\& Chobanova, S.(2020). Metabolizable energy and true digestibility of the protein of extruded of bakery by-products (bread wastes) in balanced experiments with poultry. Journal of Central European Agriculture, 21(3), 517-521.

Penkov, D.\& Genchev, A. (2018). Methods for introduction of objective criteria for bioconversion of energy and nutrients along the feed - animal products chain in meet-type poultry farming. Journal of Central European Agriculture, 19 (2) 270-277.

Penkov, D., S. Grigorova (2020). Methodology for reporting of the energy and protein transformation in the eco-technical chain "feed-egg mélange"by laying hens through introducing of "Clarc of energy distribution/Clarc of protein transformation", Trakia Journal of Sciences, 1, 20-24.

Penkov, D.\& Sv. Grigorova (2020). Influence of different biological active additives in combine fodders for layers on the transformation of energy and protein in the chain "fodder - egg mélange", Bulgarian Journal of Animal Sciences, 57 (6), 11-20, ISSN 2534-9856.

Pirgozliev V.\& Rose SP. (1999). Net energy systems for poultry feeds: a quantitative 
review, World's Poultry Science Journal, 55(1): 23-36.

Stoykov A.\& V. Katsarov (2010). Swine breeding. Acad. Publ. AU - Plovdiv, 250.

Schiemann, R., K. Niering, L. Hoffmann, W. Jench \& A. Chudy (1971). Energetische Fuetterung und Energienormen. VEB Deutscher Landwirtschaftsverlag, Berlin.

Todorov, N., Marinov \& Alexiev, A. (1995). Basic animal nutrition. ISBN 9544670122, (In Bulgarian).

Todorov, N., Marinov, B., Ilchev, A., Penkov, D., Georgieva, V., Ganchev, G.\& Chobanova, S.(2016). Applied feeding of productive animals. IFO-Design, Sofia, ISBN 9789542944126, (In Bulgarian).

Yadav, D.S., Shrivastava, M., Singh, J.P.\& Mishra, A.K. (2014). Effect of replacement of maize with bakery waste in broiler ration. International Journal of Agricultural Sciences and Veterinary Medicine, 2(1), 28-33. 